\title{
Effect of housing systems on the energy balance of laying hens
}

\author{
E. H. Ketelaars, A. Arets, W. van der Hel, A. J. Wilbrink and M. W. A. Verstegen \\ Department of Animal Husbrandy, Agricultural University, Marijkeweg 40, 6709 \\ PG Wageningen, Netherlands
}

Received 23 October 1984; accepted 28 February 1985

Key-words: housing system, energy balance, laying hen, energy utilization

\section{Summary}

In each of two experiments 192 medium large laying hens, of 19 to 27 and 29 to 42 weeks of age respectively, were put in two respiration chambers in cages and on wire floor under the same environmental conditions. Both production performance and utilization of energy were measured. Feed conversion was slightly lower in the cage system due to a larger egg weight. Moreover the hens in cages showed a larger growth rate. With about the same energy intake in Experiment 1 and a lower in Experiment 2 the better performance in cages can only be explained by a possibly slightly better utilization of the energy and in particular by a lower requirement of maintenance energy in cages.

\section{Introduction}

Comparisons of the performance of laying hens in battery cages with that of hens in various forms of floor systems have often been made both in practice and in random sample test stations (Wegner, 1968, 1971; Lüke, 1978). The results of such comparisons however are variable, probably because of a great variation in experimental circumstances such as bird density and size of units.

Apart from a lack of agreement also a physiological explanation of the observed results is not given. In particular the effect of housing systems on the energy metabolism of poultry is not known. Observations in the field however do suggest that a better production performance and in particular a low feed conversion of hens in cages may be explained for the greater part by a more efficient energy utilization in the cage system.

The purpose of this investigation was to study the energy utilization of laying hens in different housing systems in respiration chambers. 


\section{Materials and methods}

The investigation has been carried out with laying hens, type Warren SSL, in two parts: Experiment 1 (from 19 to 27 weeks of age) and Experiment 2 (from 29 to 42 weeks of age).

\section{Housing}

The hens in Experiment 1 were reared in a litter system with a half-slatted floor under natural daylight (May-July), whereas in Experiment 2 the same rearing system was used but with a constant day-length of 8 hours starting at 7 weeks of age.

In each experiment two identical respiration chambers described by Verstegen et al. (1984) were used, each time with 192 laying hens. In one chamber 96 hens were housed in 24 flat-deck cages, and in the other one 96 hens in 2 wire-floor pens $(2.5 \mathrm{~m}$ $\times 2.5 \mathrm{~m}$ ) (Fig. 1). The food trough length in the cages was $12.1 \mathrm{~cm}$ per bird.

The ventilation rate of the respiration chambers was $30-40 \mathrm{~m}^{3} / \mathrm{h}$. The air speed at bird level was $0.2 \mathrm{~m} / \mathrm{s}$. During each experiment 15 hours of light was provided by TL-33 $40 \mathrm{~W}$ armaments with a light density of 20 to $50 \mathrm{~lx}$ on bird height.

The ambient temperature inside the chambers was maintained at $20^{\circ} \mathrm{C}\left( \pm 3{ }^{\circ} \mathrm{C}\right)$ together with a relative humidity of $65-70 \%$.

The hens were fed ad libitum with a commercial diet (approx. 11.72 MJ metabo-

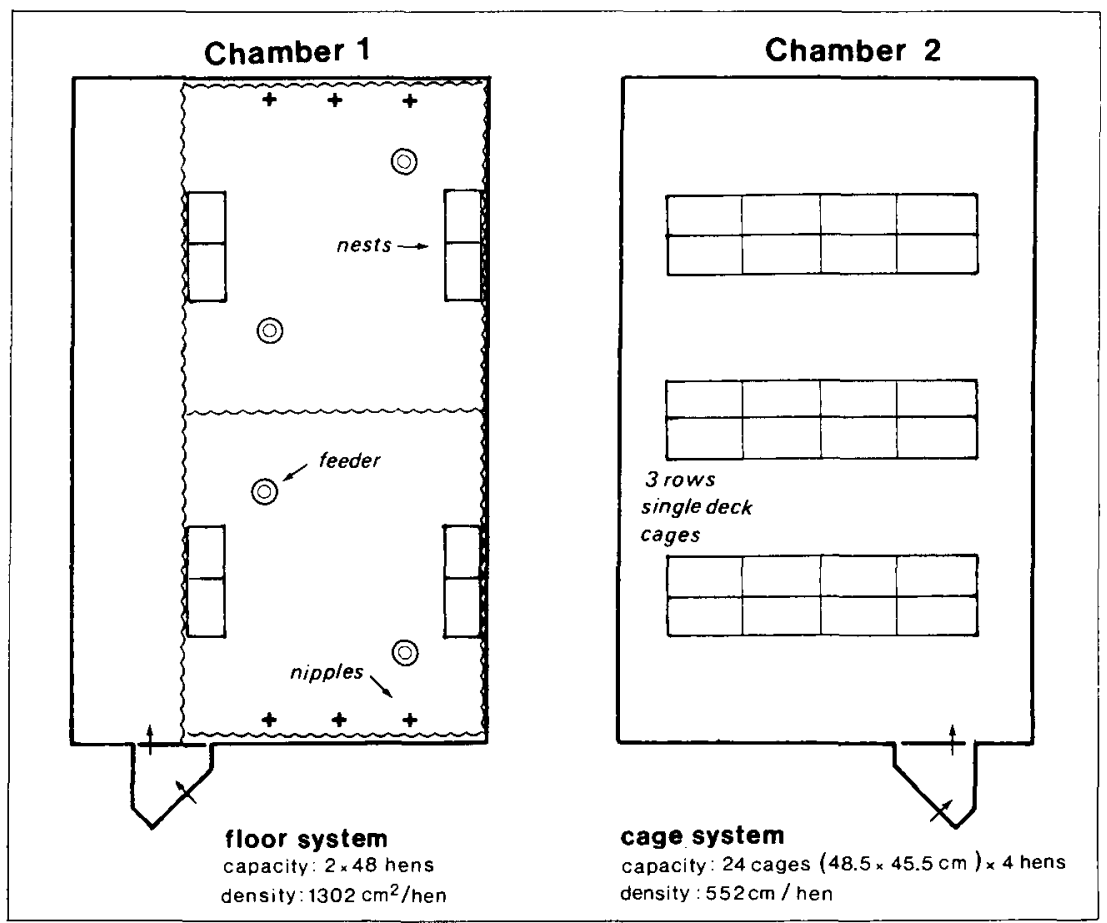

Fig. 1. Respiration chambers. 
lizable energy (ME)/kg and $16 \%$ crude protein). In both systems drinking-water was provided by nipple drinkers. Droppings were collected on metal trays, removed after 6-day intervals (balance periods) and stored at $4-5^{\circ} \mathrm{C}$.

\section{Metabolic rate and energy balance measurements}

In Experiment 1, the hens were placed in the respiration chambers at an age of 18 weeks and stayed there, after 1 week of acclimation, for 8 weeks. In each week twice respiratory gaseous exchange measurements for $2 \times 24$ hours and one complete 6-day energy balance measurement were carried out, so 16 and 8 of each measurement in total.

In Experiment 2 the experiment started when the birds were 18 weeks old and consisted of a 10-week period (18 to 28 weeks of age) in an environmentally unconditioned room, with the hens already placed in both housing systems, and of a 13week period ( 29 to 42 weeks of age) in the chambers. In the first experimental period of Experiment 2 only 4 balance measurements have been carried out. In the second period the same measurements were done as in Experiment 1, during the first 8 weeks and the last 2 weeks, so 20 respiration measurements of $2 \times 24$ hours and 14 energy balance measurements in total (Fig. 2).

During both experiments ( 9 weeks in Experiment 1, and 23 weeks in Experiment 2) egg production, egg quality, feed and water consumption and mortality were recorded. Th birds were weighed every week: 3 times individually, at an age of 18, 23 and 27 weeks, and 5 times in groups of 4 birds in Experiment 1, and 5 times individually, at an age of 19, 23, 28, 33 and 37 weeks, and 19 times in groups of 4 in Experiment 2 . In both experiments some egg eating occurred in the floor groups. The number of eaten eggs was estimated.

Energy balances were set up by measuring the feed energy input and the total energy output of the birds, i.e. the energy in the eggs and droppings, the heat production, and also the energy contents of the dust in the air and in condensation water in each chamber. The energy content was established with a bomb calorimeter.

Heat production was determined by measuring simultaneously the $\mathrm{O}_{2}$ and $\mathrm{CO}_{2}$ contents of in- and outgoing air with paramagnetic and infrared analysers respec-

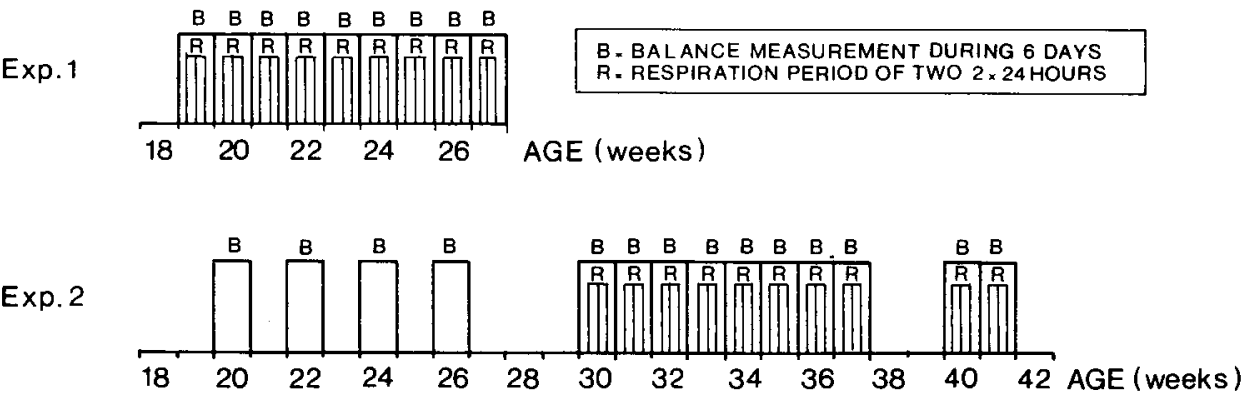

Fig. 2. Experimental design.

Neth. J. agric. Sci. 33 (1985) 


\section{E. H. KETELAARS ET AL.}

tively. After standardizing the amounts of air in terms of temperature $\left(0^{\circ} \mathrm{C}\right)$, air pressure $(101 \mathrm{kPa})$ and humidity, the actual $\mathrm{O}_{2}$ consumption and $\mathrm{CO}_{2}$ production can be calculated (Verstegen et al., 1985). From these data heat production per day was obtained with the equation of Romijn \& Lokhorst (1961):

$$
\mathrm{H}=16.2 \mathrm{O}_{2}+5.0 \mathrm{CO}_{2}
$$

where: $\mathrm{H}$, heat production in $\mathrm{kJ}$,

$\mathrm{O}_{2}$, oxygen consumption in litres,

$\mathrm{CO}_{2}$, carbon dioxide production in litres.

For the energy balance calculations egg samples were collected in Experiment 1 at an age of 24 and 27 weeks and in Experiment 2 at an age of 24, 34 and 42 weeks. These samples were analysed for both housing systems together assuming that there would be no essential difference in egg composition due to the system involved (Tolan et al., 1974). A statistical analyses was carried out with the two sample test.

\section{Results and discussion}

Egg production, feed conversion, growth and mortality data are given in Table 1. A distinction was made between eggs produced and eggs actually collected. A number of eggs, particularly in the floor system, got lost because the egg shells were badly damaged or because they had been eaten by the hens. In both experiments the number of eggs calculated on a hen-day basis did not differ between the two housing systems. The number of collected eggs however was about $1.4 \%(P<0.05)$ to

Table 1. Egg production, feed conversion, growth and mortality in two experiments with laying hens in two housing systems: cages and wire floor.

\begin{tabular}{|c|c|c|c|c|}
\hline & \multicolumn{2}{|c|}{ Experiment 1} & \multicolumn{2}{|c|}{ Experiment 2} \\
\hline & cages & floor & cages & floor \\
\hline Experimental period (age in wks) & $19-27$ & $19-27$ & $19-42$ & $19-42$ \\
\hline Eggs produced per hen-day (\%) & 54.2 & 55.0 & $\begin{array}{l}80.8 \\
91.7^{*}\end{array}$ & $\begin{array}{l}80.5 \\
90.9^{*}\end{array}$ \\
\hline Eggs produced per day per hen housed $(\%)$ & 51.0 & 53.0 & $87.9^{*}$ & $90.4^{*}$ \\
\hline Eggs collected per hen-day (\%) & 51.0 & 46.7 & $\begin{array}{l}79.5 \\
90.5^{*}\end{array}$ & $\begin{array}{l}78.0 \\
88.6^{*}\end{array}$ \\
\hline Eggs collected per day per hen housed (\%) & 48.4 & 45.0 & $86.8^{*}$ & $88.0^{*}$ \\
\hline Average egg weight $(\mathrm{g})$ & 53.3 & 51.9 & 60.5 & 59.2 \\
\hline Feed consumption per hen per day $(\mathrm{g})$ & 119.9 & 118.9 & 128.7 & 127.0 \\
\hline Feed consumption per day per $\mathrm{kg}^{0.75}(\mathrm{~g})$ & 67.9 & 68.8 & 70.2 & 71.3 \\
\hline Feed conversion ( $\mathrm{kg} / \mathrm{kg}$ eggs produced) & 3.80 & 3.82 & 2.61 & 2.64 \\
\hline Feed conversion ( $\mathrm{kg} / \mathrm{kg}$ eggs collected) & 4.04 & 4.51 & 2.65 & 2.72 \\
\hline Growth (g) & 562 & 490 & 825 & 676 \\
\hline Mortality (\%) & 5.2 & 2.1 & 6.3 & 1.0 \\
\hline
\end{tabular}

* During respiration period from 29 to 42 weeks of age. 


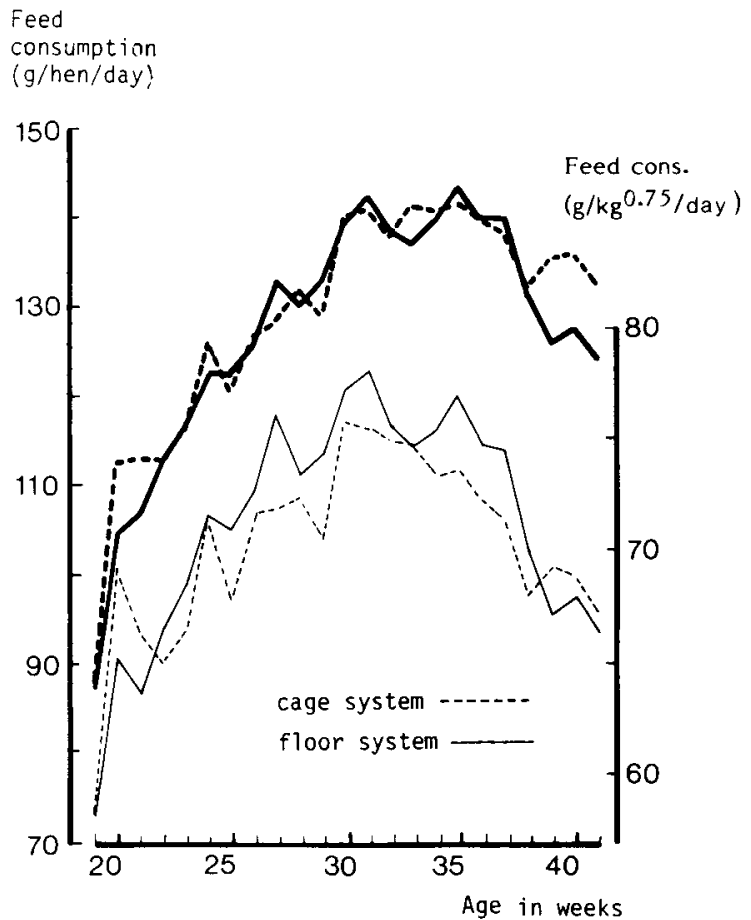

Fig. 3. Feed consumption per hen-day and per $\mathrm{kg}$ metabolic weight $\left(\mathrm{kg}^{0.75}\right)$ in $\mathrm{g}$ (Experiment 2 ).

$3 \%$ larger in the cages (Table I). Per hen housed the egg production was higher on wire floor because of a 3.1 to $5.3 \%$ lower mortality.

The average egg weight was higher in cages in both experiments. Feed consumption per bird and per $\mathrm{kg}^{0.75}$ were similar in both systems (Fig. 3). The feed conversion in the cage system tends to be lower, obviously because of the larger egg weight and particularly as far as collected eggs are concerned.

Weight gain during the laying period is significantly higher in cages than on wire floor (Table 1, Fig. 4).

Mortality in cages was somewhat higher than on wire floor in both experiments.

In the first experiment egg quality traits were compared (Table 2). The egg weight in cages is higher because of slightly heavier egg shells and albumen weight. However yolk content was reduced in cages. Egg energy was similar in both systems.

As far as egg production and egg weight are concerned the obtained results are in agreement with the results of other comparative investigations (Wegner, 1971). Differences in feed conversion however are in many cases larger. Most probably this is due to the fact that in temperate climates in winter time the cage system with its high density (more birds per unit of space) contributes to a higher ambient temperature in the house with the effect of a lower feed consumption. In our experi- 


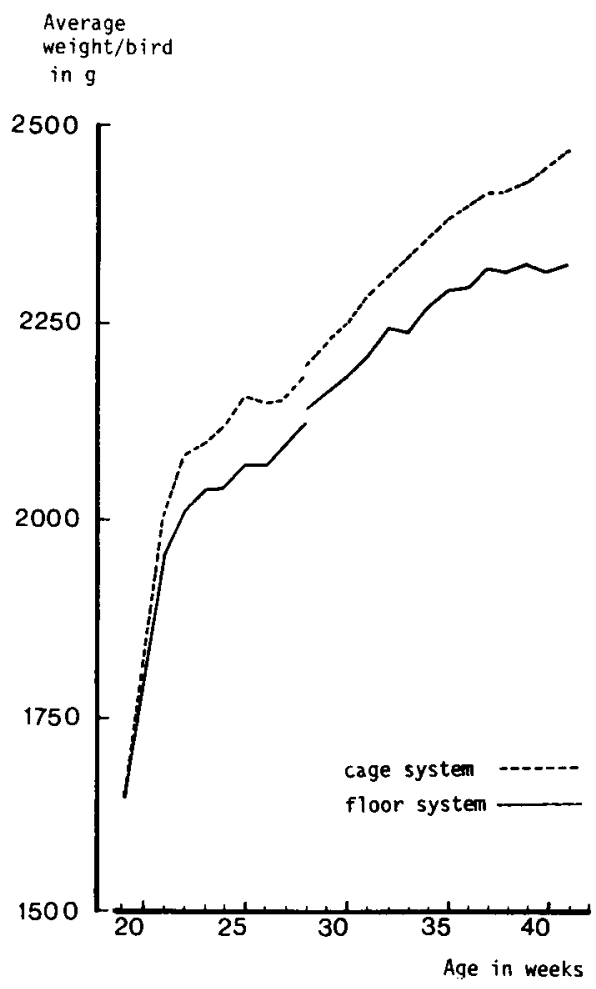

Fig. 4. Average body weights (Experiment 2).

Table 2. Egg quality traits, measured at the age of 26 weeks in Experiment 1 ( $2 \times 40 \mathrm{eggs})$.

\begin{tabular}{lcc}
\hline & Cage system & Wire floor system \\
Egg weight $(\mathrm{g})$ & $57.46^{*}$ & $55.37^{*}$ \\
Shape index & 76.11 & 75.64 \\
Shell weight $(\mathrm{g})$ & $5.30^{*}$ & $5.07^{*}$ \\
Shell percentage & 9.26 & 9.19 \\
Albumen weight $(\mathrm{g})$ & $38.64^{*}$ & $36.85^{*}$ \\
Albumen percentage & 67.07 & 66.52 \\
Yolk weight $(\mathrm{g})$ & 13.52 & 13.45 \\
Yolk content $(\%)$ & $23.56^{*}$ & $24.26^{*}$ \\
Shell thickness $(0.01 \mathrm{~mm})$ & 26.2 & 25.5 \\
Cracked eggs $(\%)$ & 1.74 & 2.13 \\
\hline
\end{tabular}

$* P<0.05$.

ments however the ambient temperature has been kept constant at a level of $20^{\circ} \mathrm{C}$.

The non-significant difference in feed conversion in our experiments, particularly on the basis of produced eggs, may indicate that the effect on feed efficiency of the cage system itself is not as large as often is assumed. The energy metabolism in 
cages, however, remains more efficient if we take into consideration the higher body weights of the birds.

More light on the energy metabolism may be thrown by considering the energy and respiration data. The results of the respiration measurements are given in Table 3 . In Experiment 2 the heat production per $\mathrm{kg}$ of metabolic weight appeared to be lowest in cages.

Respiration quotient ( $\mathrm{RQ}$ ) $\mathrm{CO}_{2} / \mathrm{O}_{2}$ is higher in Experiment 1 compared to Experiment 2. Firstly, this is due to a substantial amount of body fat deposited in Experiment 1 . Secondly, the higher egg production in Experiment 2 resulting in more $\mathrm{CO}_{2}$ deposited in the egg shells lowered the RQ.

The observed differences in heat production between Experiment 1 and 2 can be explained by the difference in production and in feed consumption. The levels of heat production fairly agree with those in literature (van Kampen \& Romijn, 1970; van Es et al., 1973; van Kampen, 1974).

Energy balance (EB) data are given in Table 4. The intake of ME per unit of metabolic weight differed significantly only in Experiment 2, being lower in the cage system. The same observation was made by Grimbergen (1970) who found a ME intake of 837 and $879 \mathrm{~kJ} \mathrm{~d}^{-1} \mathrm{~kg}^{-0.75}$ for birds in cages and birds on litter, respectively, in the same production period (30-42 weeks of age). The heat production per $\mathrm{kg}^{0.75}$ of the birds in cages was $5.8 \%$ lower in Experiment 2, but there was no significant difference in Experiment 1. In both experiments the hens in the investigated

Table 3. Respiration data and heat production of laying hens in two housing systems. Between brackets (SD).

\begin{tabular}{llllll}
\hline & \multicolumn{2}{l}{ Experiment 1 } & & \multicolumn{2}{l}{ Experiment 2 } \\
\cline { 2 - 3 } \cline { 5 - 6 } & cages & floor & & cages & floor \\
& & & & \\
$\mathrm{O}_{2}$ consumption $\left(\mathrm{l} \mathrm{d}^{-1} \mathrm{~kg}^{-0.75}\right)$ & $27.2(1.5)$ & $27.5(1.4)$ & & $30.1(1.0)$ & $32.0(1.2)$ \\
$\mathrm{CO}_{2}$ production $\left(\mathrm{l} \mathrm{d}^{-1} \mathrm{~kg}^{-0.75}\right)$ & $25.0(1.1)$ & $25.3(0.8)$ & & $25.8(1.0)$ & $27.4(1.1)$ \\
$\mathrm{RQ}$ & $0.92(0.05)$ & $0.92(0.04)$ & & $0.86(0.02)$ & $0.86(0.02)$ \\
Heat production $\left(\mathrm{kJ} \mathrm{d}^{-1} \mathrm{~kg}^{-0.75}\right)$ & $566(28)$ & $572(25)$ & & $614(18)$ & $650(25)$ \\
\hline
\end{tabular}

Table 4. ME intake, heat production, egg energy (EE) and the energy balance (EB) in $\mathrm{kJ}$ per $\mathrm{kg}^{0.75}$ per day.

\begin{tabular}{lccccc}
\hline & \multicolumn{2}{l}{ Experiment 1 } & & \multicolumn{2}{c}{ Experiment 2 } \\
\cline { 2 - 3 } \cline { 5 - 6 } & cages & floor & & cages & floor \\
Age of birds (weeks) & $19-27$ & $19-27$ & & $29-42$ & $29-42$ \\
ME intake & 757 & 741 & & $876^{*}$ & $900^{*}$ \\
Heat production & 566 & 572 & & $615^{* * *}$ & $650^{* * *}$ \\
Egg energy & 98 & 94 & & 265 & 264 \\
Energy balance & 93 & 75 & -3 & -13 \\
ME/GE $(\%)$ & $73.2^{*}$ & $70.5^{*}$ & & 72.8 & 72.6 \\
\hline
\end{tabular}

* $P<0.05$; ** $P<0.001$.

Neth. J. agric. Sci. 33 (1985) 
housing systems had a similar energy balance, as no significant differences were observed in EB, although there was a slight tendency for a higher EB in battery cages. According to Table 1 (Experiments 1 and 2) and Fig. 4 (Experiment 2) hens gained weight during the balance period. However according to Table 4 hens in Experiment 2 did not gain energy. This indicates that the hens lost body fat and gained body protein. Wilbrink (unpublished data) indeed found that these hens had a positive protein gain. In Experiment 1 the metabolizability of the feed was better in cages (Table 4).

A lower intake of $\mathrm{ME}$ in the cage system together with a lower heat production and at the same time no difference in egg energy (EE), with a tendency to a somewhat higher $\mathrm{EB}$, demonstrates the comparatively higher efficiency of this system (Fig. 5). This may be illustrated by an estimation of the required energy for maintenance in both systems. Assuming an efficiency of 0.75 for egg production and growth, maintenance energy requirement $\left(\mathrm{ME}_{\mathrm{M}}\right)$ can be derived from the equation $\mathrm{ME}_{\mathrm{M}}=\mathrm{ME}$ intake - EE/0.75 - EB/0.75. In Experiment 1 the thus calculated $\mathrm{ME}_{\mathrm{M}}$ for the caged birds was $502 \mathrm{~kJ}$ ME per $\mathrm{kg}^{0.75}$ per dag and $516 \mathrm{~kJ}$ for the birds on wire floor. In Experiment 2 these estimates were 527 and $565 \mathrm{~kJ} \mathrm{~kg}^{-0.75} \mathrm{~d}^{-1}$ for cages and wire floors respectively. This difference is probably due to a difference in heat production as a consequence of a different activity of the hens in these systems. Arets (unpublished data) noticed that activity related to heat production was higher in hens on wire floor than in cages. This agrees with the increased heat production for these hens. Data found here indicate therefore that housing systems will effect efficiency of egg production by altering the requirements for maintenance. Therefore it is important to evaluate energy requirements for hens with regard to the systems in which they are housed.

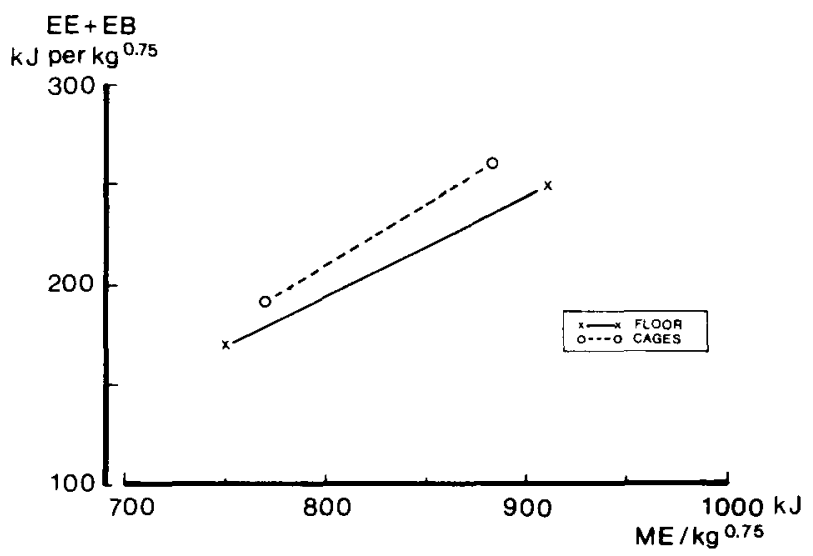

Fig. 5. Relation between ME intake and SUM of EE and EB in each housing system in Experiments 1 and 2 . 


\section{References}

Arets, W. L. M., 1981. Vergelijking van twee huisvestingssystemen van leghennen met behulp van respiratiemetingen in klimaatcellen. (Dutch.) Student thesis, Agricultural University, Wageningen.

Es, A. J. H. van et al., 1973. Thermoneutral zone of laying hens kept in batteries. Zeitschrift für Tierphy. siologie, Tierernährung und Futtermittelkunde 32: 121-129.

Grimbergen, A. H. M., 1970. The energy requirements for maintenance and production of laying hens. Netherlands Journal of Agricultural Science 18: 195-206.

Kampen, M. van \& C. Romijn, 1970. Energy balance and heat regulation in the White Leghorn fowl. In: A. Schürch \& C. Wenk (Eds.), Energy metabolism of farm animals, pp. 213-216. Juris Druck Verlag, Zürich.

Kampen, M. van, 1974. Physical factors effecting energy expenditure. In: T. R. Morris \& B. M. Freeman (Eds.), Energy requirements of poultry, pp. 47-49. British Poultry Science Ltd., Edinburgh.

Lüke, F., 1978. Leistungsvergleich verschiedener Herkünfte von Legehennen in Boden-und Käfighaltung. Deutsche Geflügelwirtschaft 31: 764-765.

Romijn, C. \& W. Lokhorst, 1961. Some aspects of energy metabolism in birds. Proceedings 2nd Symposium on Energy Metabolism (Wageningen): 49-59.

Tolan, A. et al., 1974. Studies on the composition of food. 5. The chemical composition of eggs produced under battery, deep litter and free range conditions. British Journal of Nutrition 31: 185-200.

Verstegen, M. W. A. et al., 1985. Indirect calorimetry with large groups of animals. In preparation.

Wegner, R. M., Leistungsvergleiche zwischen Käfig- und Bodenhaltung und zwischen verschiedenen Käfigsysteme, Käfiggröszen und Besatzdichten. Archiv. für Geflügelkunde 32:438-443.

Wegner, R. M., 1971. Die Intensivhaltung von Geflügel under besonderer Berücksichtigung der Käfighaltung, Teil I-II. Deutsche Geflügelwirtschaft 23: 215-217, 240-243.

Wilbrink, A. J., 1982. Vergelijking van twee huisvestingssystemen voor leghennen m.b.t. fysiologische and produktiekenmerken. (Dutch.) Student thesis, Agricultural University, Wageningen. 